\title{
Intermédialités
}

Histoire et théorie des arts, des lettres et des techniques

Intermediality

History and Theory of the Arts, Literature and Technologies

\section{Letter to A. and A. (About moving on, moving through... )}

\section{Vera Frenkel}

Numéro 6, automne 2005

Remédier

Remediation

URI : https://id.erudit.org/iderudit/1005511ar

DOI : https://doi.org/10.7202/1005511ar

Aller au sommaire du numéro

Éditeur(s)

Centre de recherche sur l'intermédialité

ISSN

1705-8546 (imprimé)

1920-3136 (numérique)

Découvrir la revue

Citer ce document

Frenkel, V. (2005). Letter to A. and A. (About moving on, moving through... ).

Intermédialités / Intermediality, (6), 143-177. https://doi.org/10.7202/1005511ar 


\title{
Letter to $A$. and $A$. \\ (About moving on, moving through ... )
}

\author{
Vera Frenkel
}

\section{I: First...}

Early in preparing this dossier, it was thought that my art historian colleagues Anne Bénichou and André Habib would be interlocutors for the project and that together we would create a conversation in print exploring the issue of "remediation" as it informs my work. What the reader will receive instead are my informal notes, without critique or embellishment.

And yet, the truth is that it's nearly impossible for me to talk about my work.

Not only because the projects travel and each different venue requires that the work be physically reconfigured;

not only because the conceptual climates into which the work is received are in constant flux;

not only because the media I place in combination and allow to interrogate each other invite destabilizing contradictions;

and not only because once an exhibition is over, the work disappears.

All of which is no more true for me, of course, than it is, intentionally or not, for contemporary artists in general. But the most elusive aspect of my practice, the characteristic that is both its strength and its nemesis resides in the transitions that occur as a work migrates from one medium into another, reemerging, like any mischievous shape-shifter, as something else.

Most of the time I don't give much thought to this process. It is so familiar that I can't imagine working in a less fluid way. But in the context of the theme I have been invited to consider (in a journal, after all, devoted to tracking the elusive and the inchoate), I will try to unfold for you my practice of many years regarding both its processes of remediation and some reference to what persists of the work's essence despite media-imposed transformations. 
When considering these transformations in the bars and the conference rooms where such thoughts are aired, a particular cluster of questions is being asked with increasing persistence:

- Should new media works be "preserved" via sequential migration into ever more current forms, or just carefully documented?

- Should they, as I wondered aloud at a recent public discussion on new media histories, be allowed simply to disappear?

- At what stage does this choice become an issue of aesthetic euthanasia, knowing how to keep a work alive (or preserved as if alive, i.e., embalmed with skill), versus accepting the release of the artwork into memory?

- And who will oversee the triage?

I will leave to experts the resolution of this issue. I raise it here only because

144 I collide with it at every turn and thought I might reduce its power by first revealing its insistence, and then by asking you to agree with me that all culture is in some sense a form of "broken telephone;" a child's circle game, each player whispering into the ear of the next, hoping the other hears what was said and is able and willing to pass it on.

With respect to remediation, it is not only the child beside us in the circle that provides the listening ear, or-no less metaphorically-the next generation that receives and somehow transmits, but with the arrival of each new technological discovery at exponentially increasing speed, the imperative of "speaking" into it, assuming that it will pause long enough to "hear" and convey what it has heard.

For valid reasons the conversation with my two gifted art history colleagues has not yet taken place, though I understand that it will happen, as many things do nowadays, pace the threat of power overload, online.

Professor Bénichou has written with great insight on my earlier work and Editor Habib has the responsibility of bringing this talking fish, me, the guest artist, onto dry land and into focus. I look forward to their interventions, traversing the surfaces of the Moebius strip that is the relation between artist, scholar and reader, in a process that will take my thinking into unpredictable directions.

In the meantime, being neither writer, nor art historian, I can offer only some personal notes on what I do and perhaps what I was thinking at the time of making this or that work. It's a start. 
Since these notes were written as one side of a discussion triangle with Anne and André in mind, their presence informs the way I wrote, and, as context for the accompanying images, I have retained the preliminary thoughts I sent them. ${ }^{1}$

Here, then, is what I wrote.

1. Some months after this letter to Anne and André was written, while I was in Kingston, I had the pleasure of meeting Alain Depocas, Head of Research at the Fondation Daniel Langlois, and in the course of the conversation learned about Permanence through Change: The Variable Media Approach, the bilingual anthology he has edited with John Ippolito and Caitlin Jones (Guggenheim Museum Publications, 2003) on precisely the issue of remediation. I wish I'd known of this sooner. It is a timely and perceptive amalgam of current thinking on the very issues I struggled to discern and express, and a valuable resource. I won't re-attempt a more informed account of the serial media migration in my work, but simply want to signal that being more attuned to the research will make a more informed account possible. 


\section{2: Instead...}

Dear Anne, dear André,

Thinking about aspects of my work that indicate remediation or what is often referred to as "media migration," and of the 146 technical and conceptual trajectories involved, two instances come to mind.

On the first, and simplest, level of movement from one medium to another:

- A completed installation (The Screening Room, Minneapolis,1983) serves as mise-en-scène for the next production, a videotape (The Last Screening Room, Toronto, 1984);

- A voice-over text for the "cargo-cult" passage in a performance work (Mad for Bliss, Toronto, 1989), becomes the narrative armature for a videotape (This Is Your Messiah Speaking, Newcastle, 1990), which in turn transmutes into an animation sequence for the Piccadilly Circus Spectacolor Board (Messiah Speaking, London, 1991). 

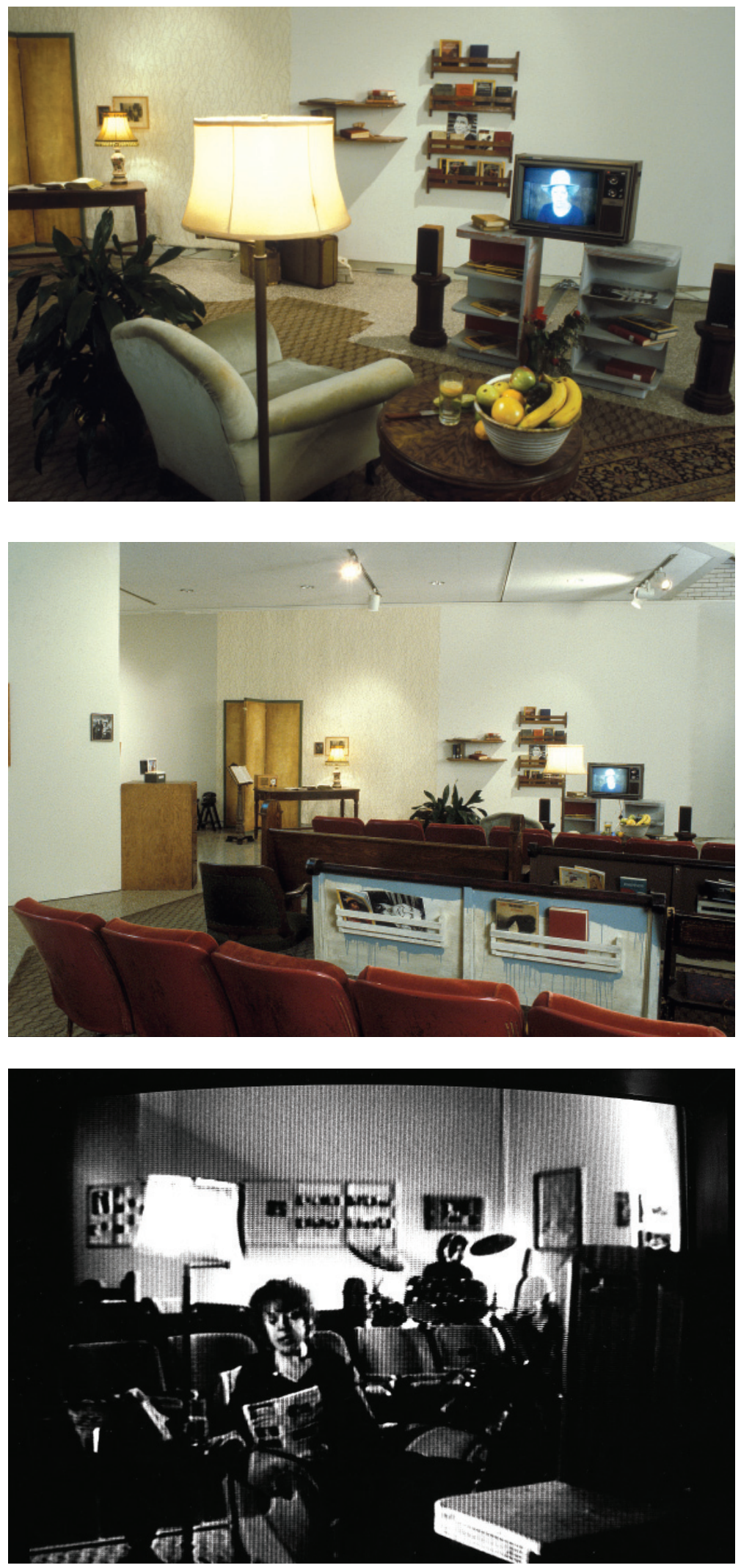


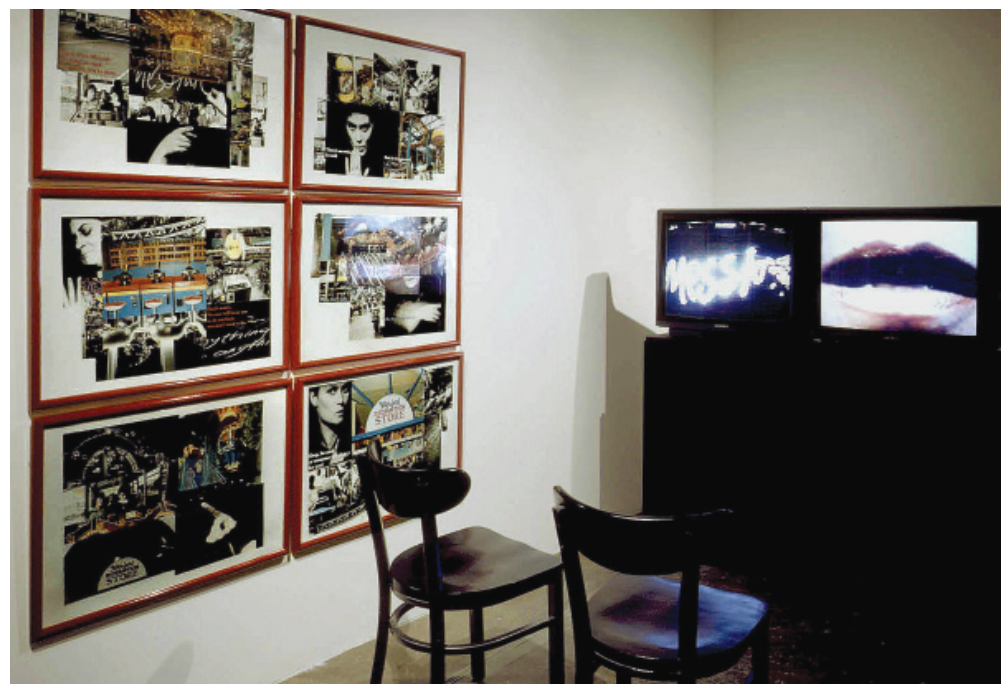

148
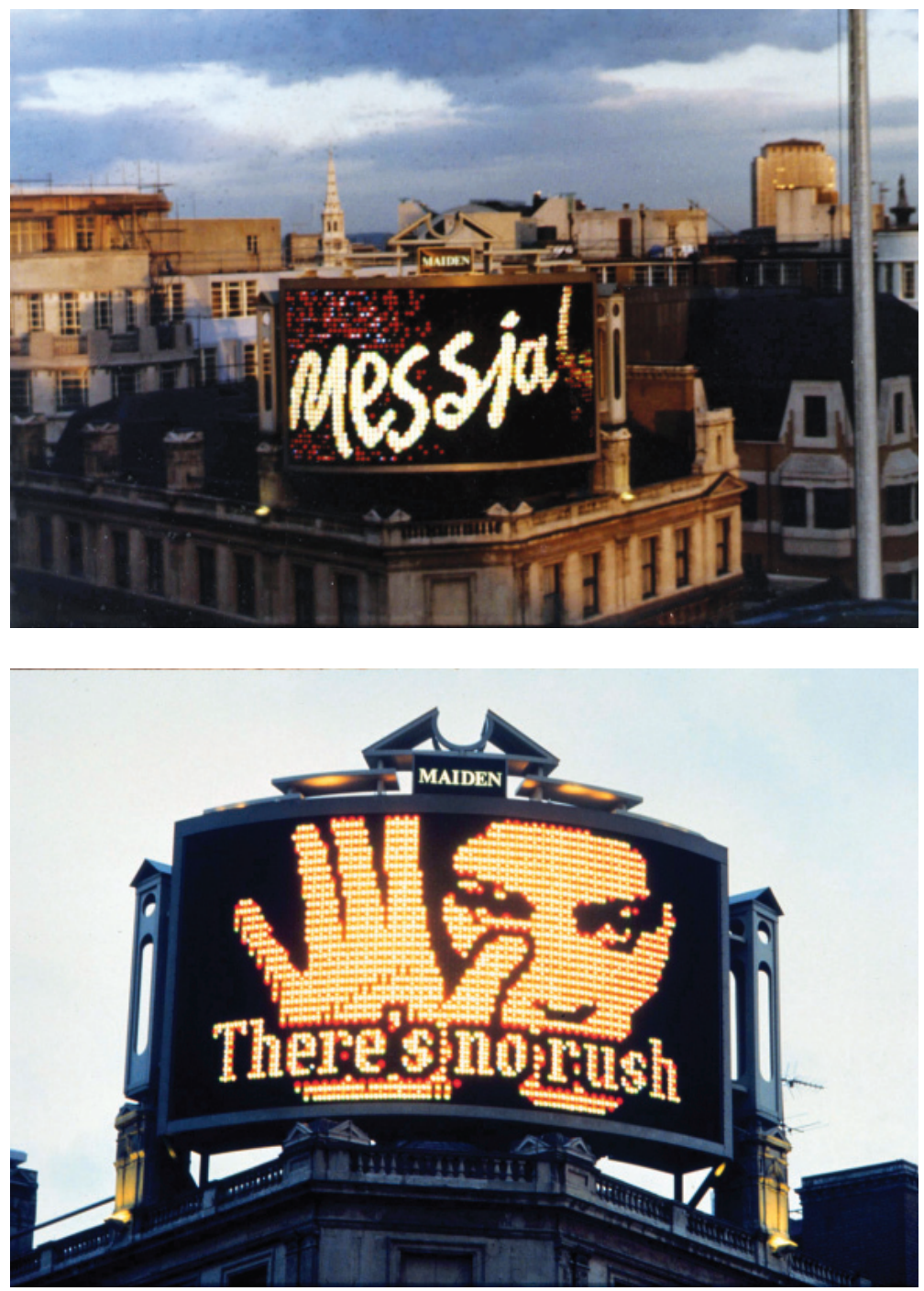
A second level of migration concerns the fate of a given thematic focus as it moves through a sequence of media, governed by the parameters of each in turn. The issue is how this focus survives through a linked and layered process of migration that resembles not so much a daisychain or palimpsest, but rather a kind of double helix, the theme inhabiting one spiral, the changing form the other, with the two strands interdependent. Something survives; something changes, and forces of chance help to bind these elements into a new entity from which emanates the uncanniness of an apparent but indescribable family resemblance.

Whether the journey traced is from performance to videotape to computer animation, as described above, or from video installation, storytelling and music to photography, printmaking, and text, as will be described below, the ways in which concepts and imagery find new meanings while retaining their essences remain intriguing.

The Messiah Project, with its focus on the so-called "cargocult" at the core of the romance of consumerism, went through three distinct shifts before opening out into another work entirely: “...from the Transit Bar," a six-channel videodisk installation and functional piano bar built for documenta IX (Kassel, 1992), where consideration of the costs of false consciousness were this time expressed through accounts of personal migration and loss told by fourteen of my friends. The Transit Bar's interwoven video narratives address issues of displacement, deracination, and the learning/unlearning of cultural memory. It is a work haunted by awareness of the power over one's fate that can be wielded 
by a bureaucrat or functionary under a totalitarian regime, especially a regime with "cargo-cult" tendencies attached to the mantra of "a thousand years of bliss," a mantra that characterizes certain ritual practices from Papua New Guinea to Third Reich Germany.

On my return to Canada from Kassel, trans-media shifts continued with the exhibition Raincoats, Suitcases, Palms (A.G.Y.U., Toronto, 1993) which included installations such as Recovering Memory (containing the palm trees, bar rails, suitcases and Disklavier from the documenta Transit Bar), and Journey (a suite of three ten-foot long photo-murals interweaving Transit Bar imagery and props with related visual material on bereavement). The exhibition catalogue

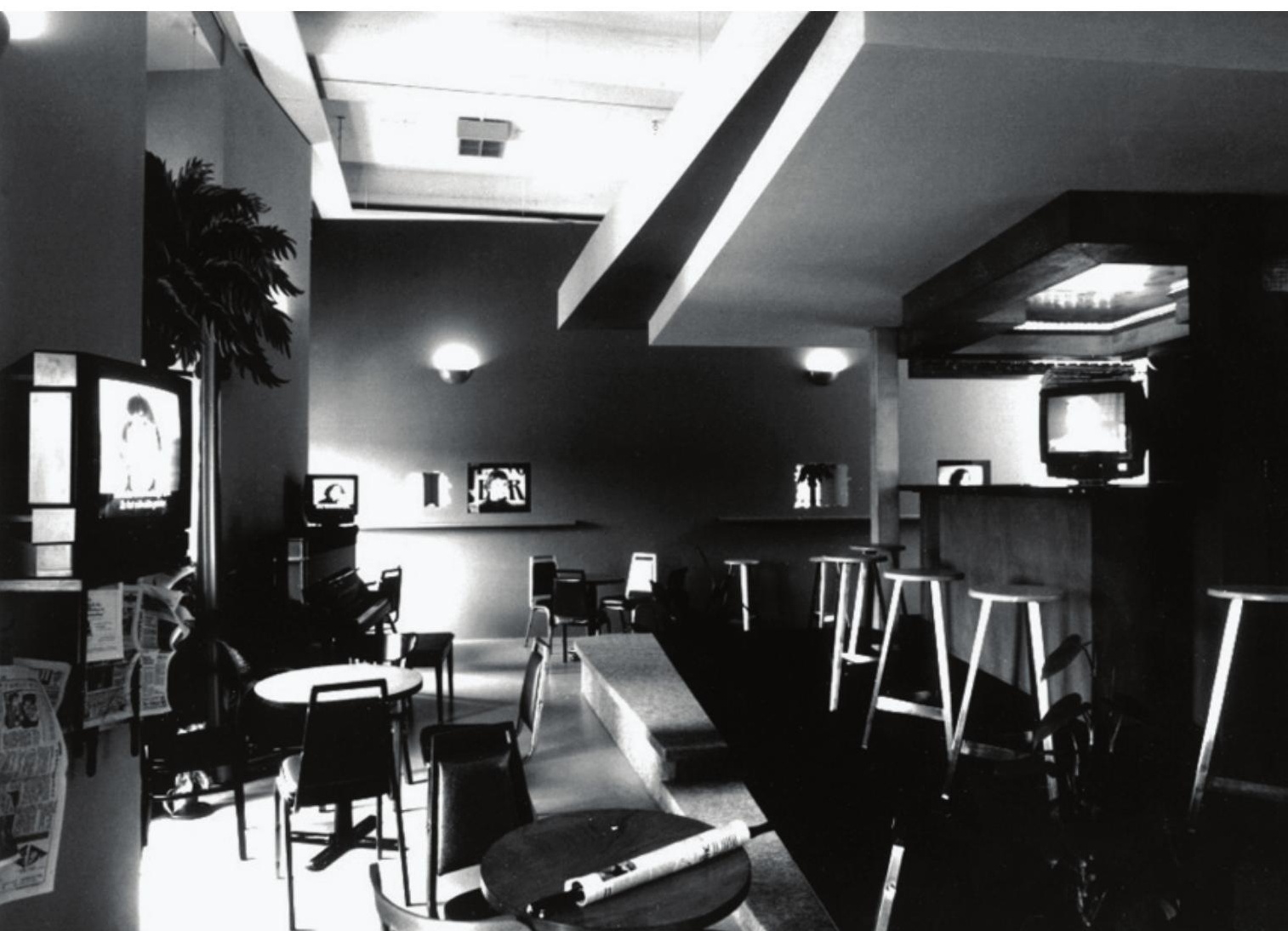


was twinned with an artist's book, The Bartender's Report, a distillation into a kind of prose poetry of the themes of migration and loss permeating these works.

A year later, when art historian and curator Sigrid Schade invited me to create a site-specific work for the exhibition Andere Körper (Other Bodies, Linz, 1994), I found myself in residence at a former Wehrmacht prison that housed the Offenes Kulturhaus in Linz (later the OK Centrum für Gegenwartskunst, the main centre for contemporary art in Upper Austria).

While researching the history of the city of Linz and still mindful of the power of a document or rubber stamp, or

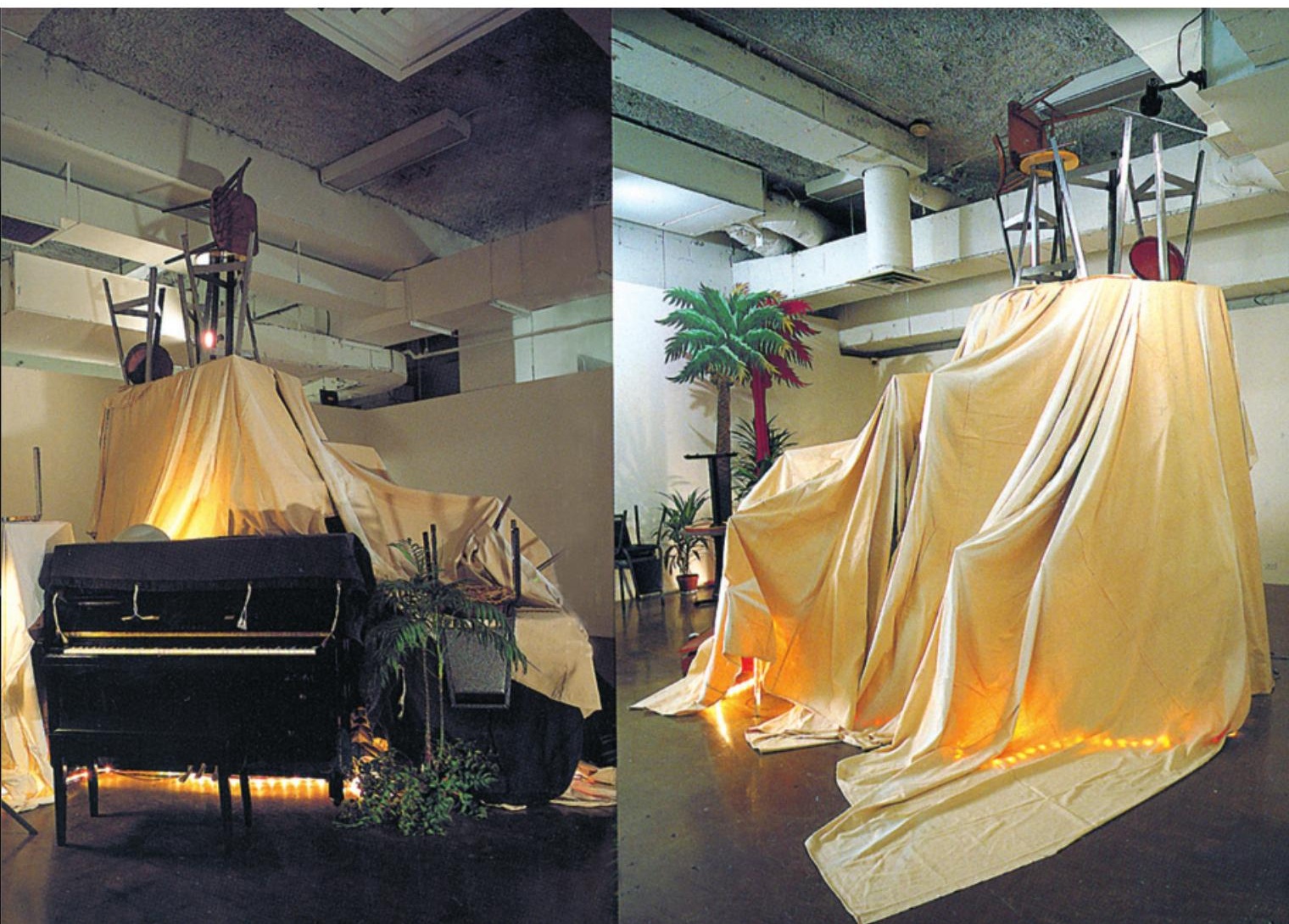


its absence, to affect one's life, I encountered two main signifiers: Linzer torte (a famous local pastry) and Adolf Hitler (an infamous native son). More recently there has also evolved in Linz the Ars Electronica Festival, a prestigious international gathering of new media theorists and practitioners (a fine showcase for the results of inspiration, perhaps, but hardly its source). The impact on Linz of the new Ludwig Boltzmann Institute ${ }^{\mathrm{TM}}$ on media research, practice and conservation (scheduled to open next fall under the direction of Dr. Dieter Daniels, currently Professor of Art History and Media Theory, Academy of Visual Arts, Leipzig) remains to be seen.

I tasted the torte of course, and also walked the few blocks from the Offenes Kulturhaus on the Dametzstrasse to where

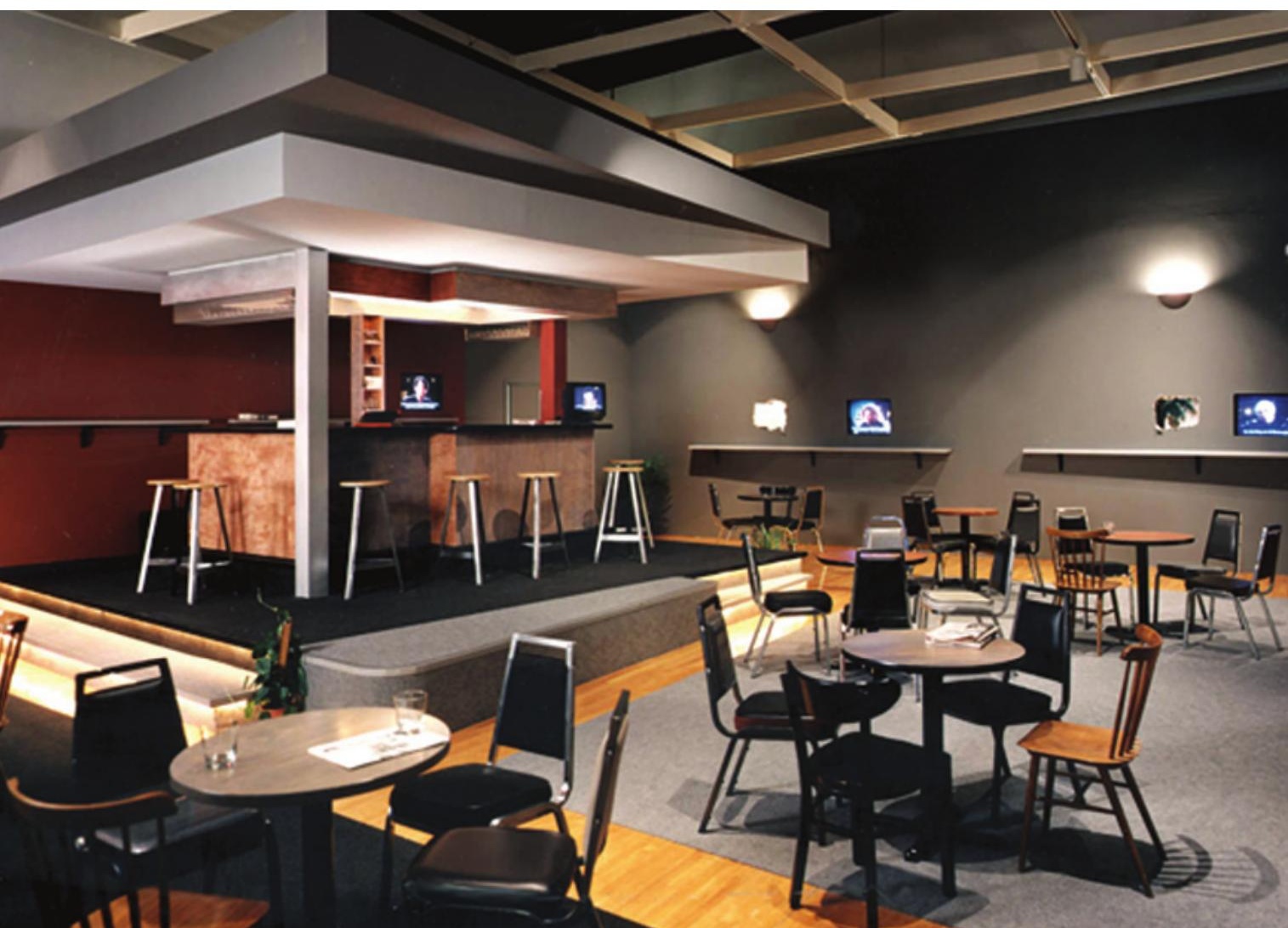


that street becomes the Humboldtstrasse. There, gazing up at the apartment block where young Adolf had lived with his mother and sister, and seeing the row of sex shops and hearing-aid centres that then occupied the building's ground floor, I made my decision. How could I resist (I thought at the time) reflecting a milieu with such a history that now ministers to the horny and the deaf? Hitler was clearly a more compelling subject than was the pastry.

The resulting multi-channel video work, Body Missing, was installed throughout the exhibition spaces, stairwells and front façade of the OK, and was later extended via the Internet (www.yorku.ca/BodyMissing) into a web-based installation. Two related image-text projects followed, and, with the help of the Goethe-Institut Toronto, six large digital 


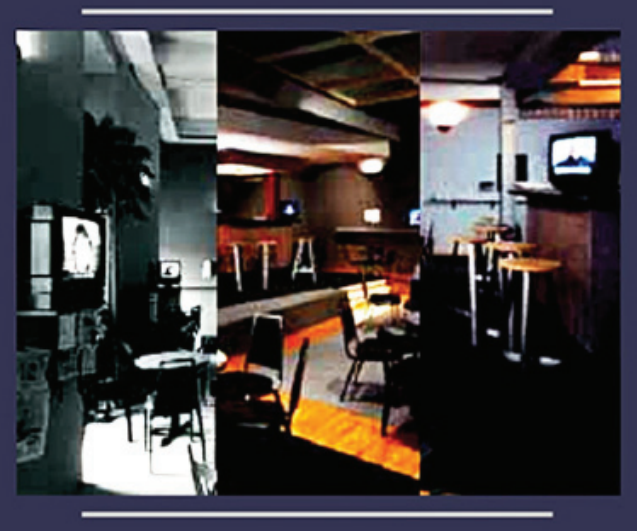

154

\section{På genomresa ... ...Passing through the town Auf der Durchreise durch die Stadt... En traversant la ville ...}

photo-murals were added, one for each video station, for the Detroit and Toronto Body Missing installations in 2000.

The conceptual beginnings of this work began in Vienna, when I was visiting artist at the Akademie der bildende Künste, and I saw in the exhibition Kunst und Diktatur (Art and Dictatorship) a Grundriss or floorplan sketched by Hitler in his bunker for the unrealized Führermuseum that he fantasized building in Linz. Seeing the drawing resonated with my accidental discovery of corridors of dusty art crates at the Akademie. A phone conversation with Norbert Schweizer, then production manager at the Offenes Kulturhaus, resulted in the assignment of a camera team to Vienna, and the work began. 
I remembered a long-ago conversation about Linz with a dear friend, the late Dr. Alan Powell, a sociologist, who surprised me at the time with his expertise on the Third Reich. Alan was still alive when I began to research the complex bureaucratic procedures that were devised under the clandestine Sonderauftrag Linz (Special Assignment, Linz) which facilitated the theft from all of Europe of artworks destined for the proposed museum which Hitler imagined would outshine in scale and importance the Uffizi or the Louvre. I looked forward to reporting back to Alan what I had discovered, but he was already ill with the infection caused by what later came to be identified in Canada as the Red Cross "tainted blood scandal."

\section{(a) ... THE SENSE PERSISTS OF ...}

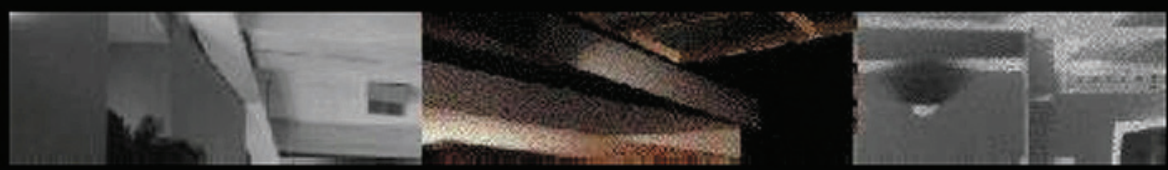

This (or any bar) will do, as long as the drinks are the way you like them,

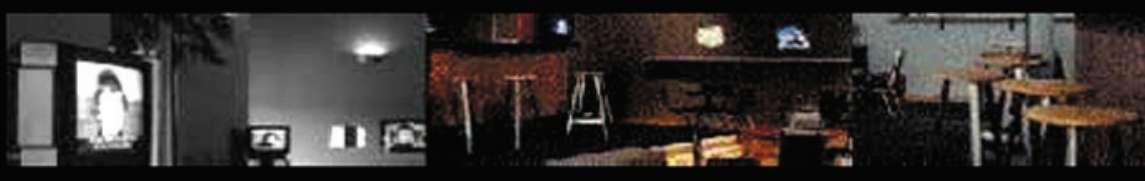

the bartender's a listener, and the sense persists

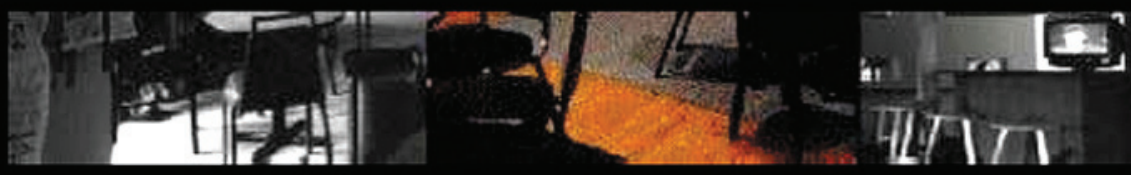

of something compelling beyond these comforts. 
Bady Wiving Pony Lite fanep Findivident Quear, ep. Bantereders, Oxyo, , thisis -

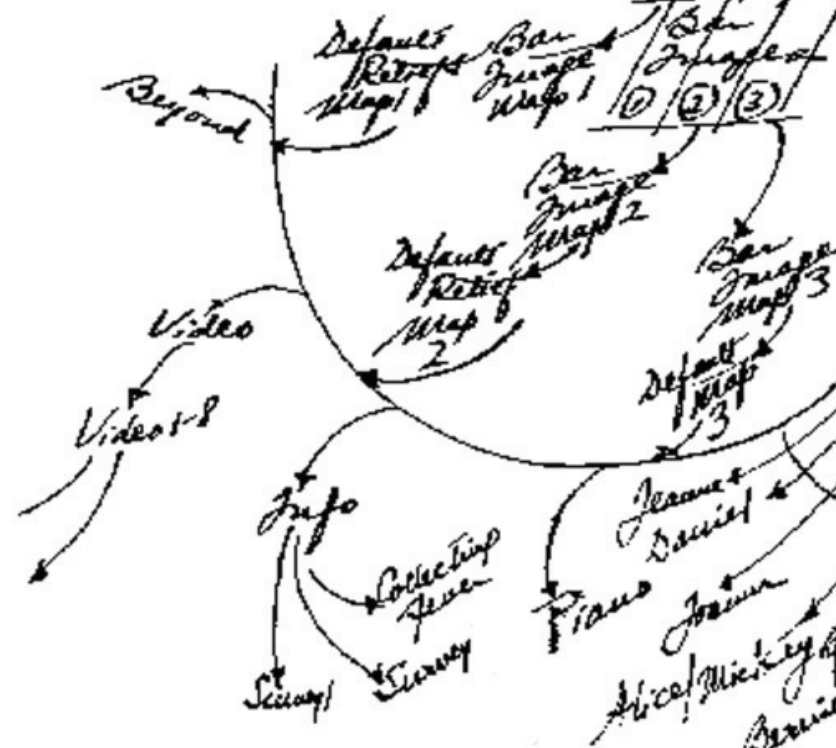

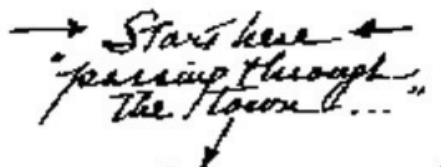

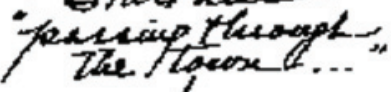

sives

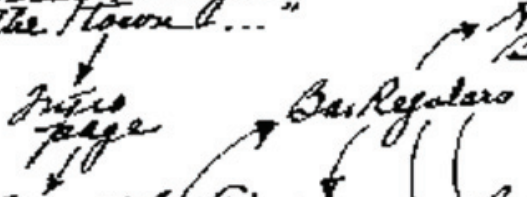

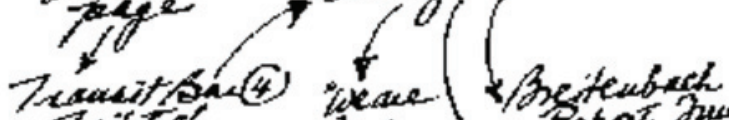
$7 x+x_{0} \alpha$

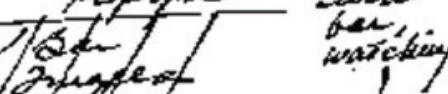

$\frac{10\left(\frac{2}{2}\right) /(3) /}{7}$

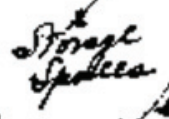

1

Pesori, puse 49
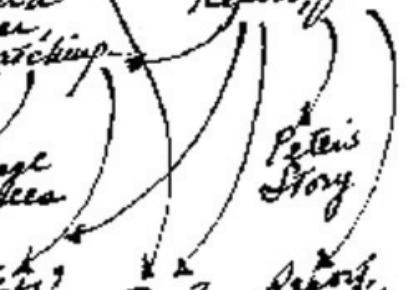

á

$$
\text { , }
$$




\section{The Bartenden's

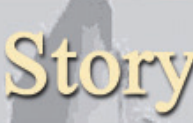 \\ IS
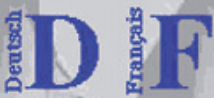

"They meet at the bar where I work. At least two of them are artists. One of the women is quite old. Somebody said she was Paula Scholl (Polly), the brilliant art restorer.
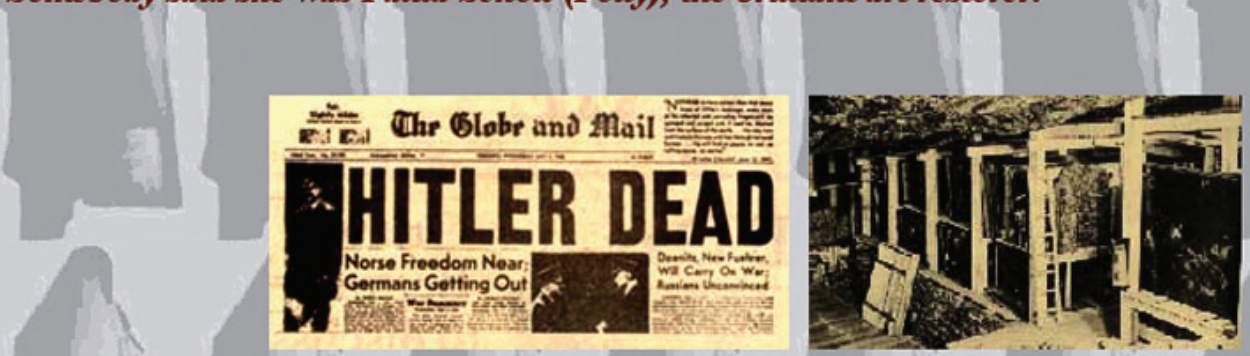

"Our other regular patrons are the local taxi drivers. We're too far from the station to be their main meeting place. But for the foreign drivens, the Transit Bar is a favourite mid-town hangout. They know everything about those political meetings: where they're held, when, who attends, for how long ...

"Nights when I'm on duty alone, I can work my way from one side of the bar where the talk is of suspicious late-night meetings, to the other side and numouss of artworks originally destined for the unrealized Hitlermussenm. The same story, sort of."
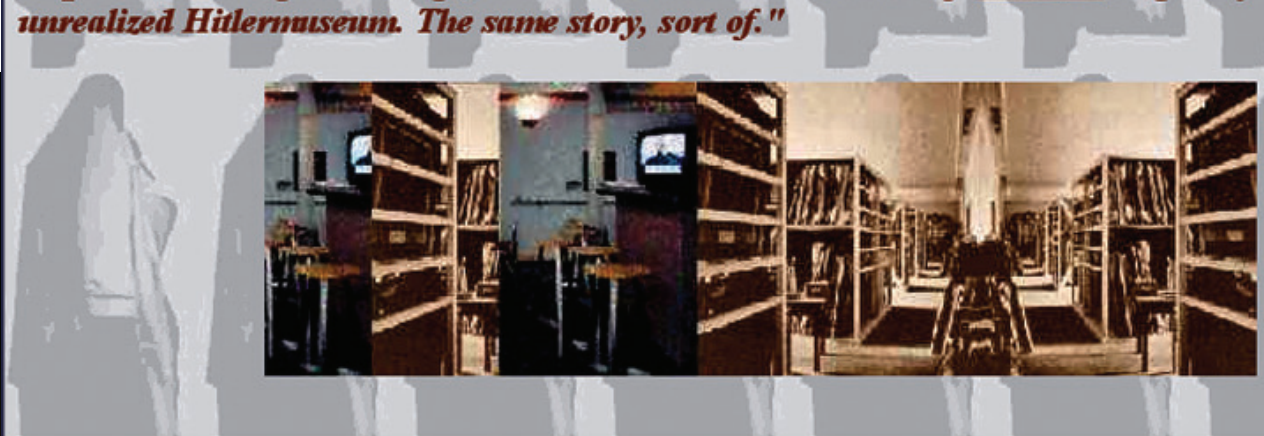
With this in the background, my increased awareness of the bureaucratic Kunstpolitik procedures alerted me to similar tropes closer to home and helped to shape a subsequent project, but in the meantime, the Sonderauftrag Linz. underscored, in my view, the ways in which life, death and art were measured, documented and processed in that city during the Third Reich, ostensibly for cultural purposes. Madness is madness whether in the service of the healthsystem or of art.

158 Even given that knowledge, I nevertheless could not have predicted the chaotic and neglected state of the section of the city archives which housed the many drawings, models and photographs of this Lieblingsprojekt of Hitler's, as if in silent resistance to the power and the order that the material had once represented.

Although originating as a transient, site-specific work, Body Missing has travelled since to museums and art galleries on four continents, returning to Austria twice (installed at the OK again in 1996; and at the Georg Kargl Gallery, Vienna, 2001-2). Plans by art historian and museologist Gottfried Flied to install a new version of this work at the Sigmund Freud Museum in Vienna developed instead into an installation at the Freud Museum in London, 2003, where the project was the focus of From Theft to Virtuality: Considerations of the Meaning of Absence, an international conference chaired by art historian Griselda Pollock at the Institute of Contemporary Art, London. 


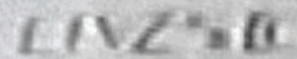

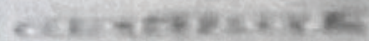

\section{Steploystep (to reconstruct the ant Chet is wissing from memory,}

\section{Netscape: and they had their histories ...}

The Piano Players
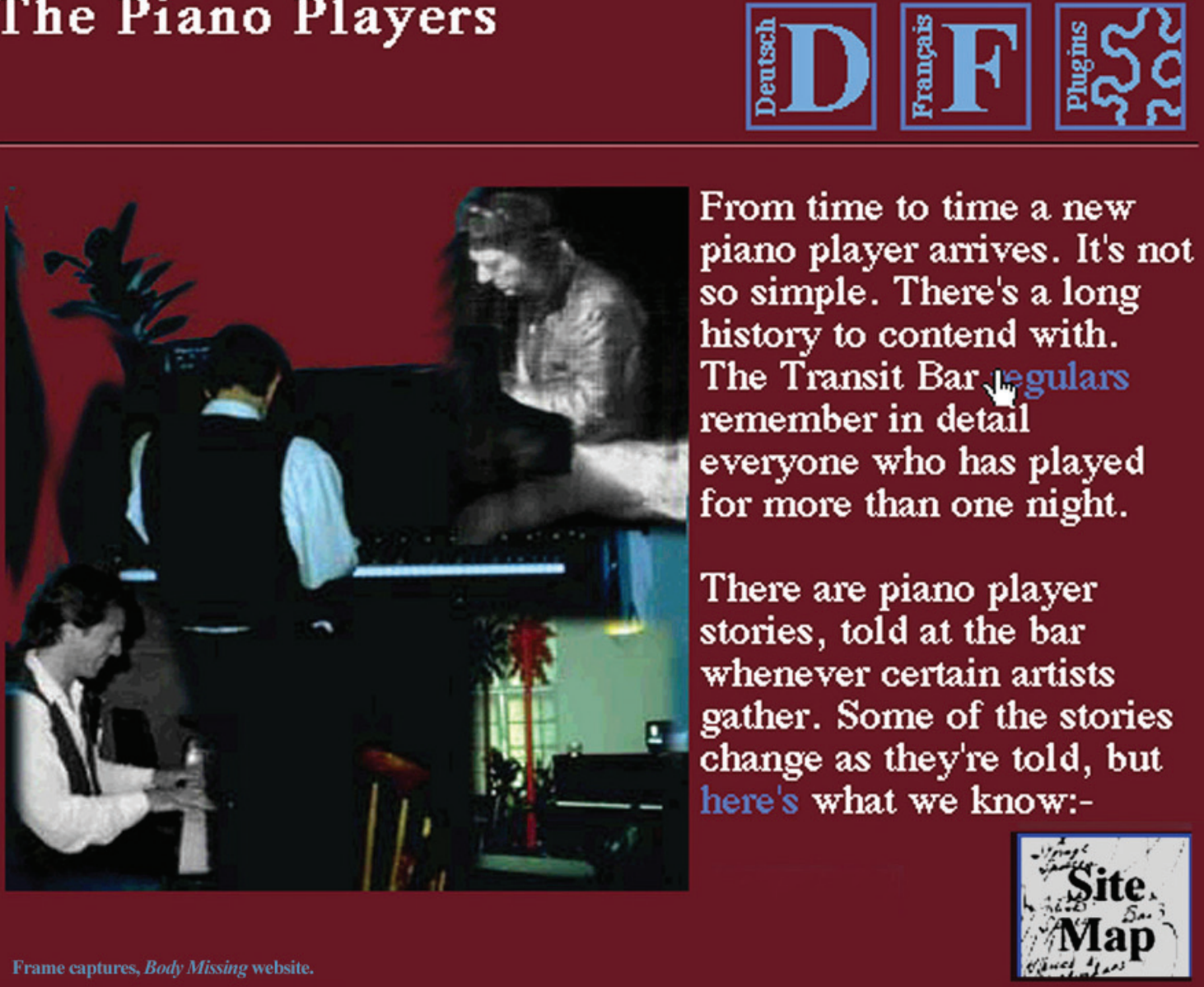


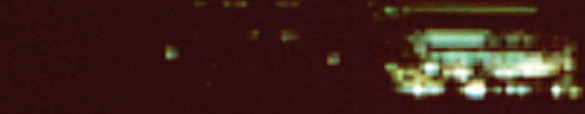

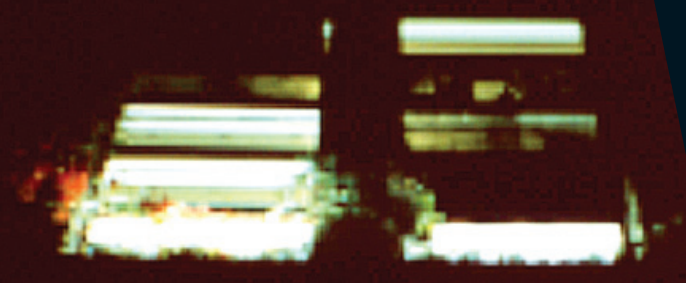
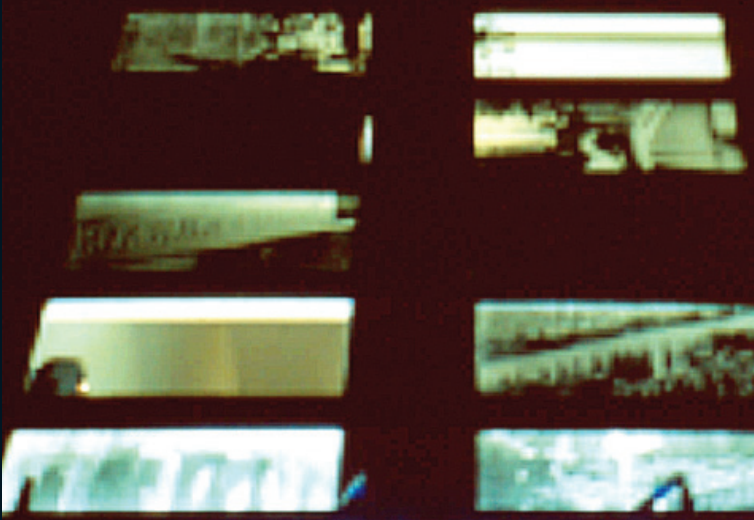

OFFENES
Body Missing is now again in Vienna where gallerist Georg Kargl is planning to place the work permanently.

"This work must remain in Austria," he has said, "this is where the work belongs." At the moment, the Body Missing crates, safely stored chez Kargl, resemble uncannily those that I had seen in the basement corridors of Vienna's Akademie der Bildende Künste

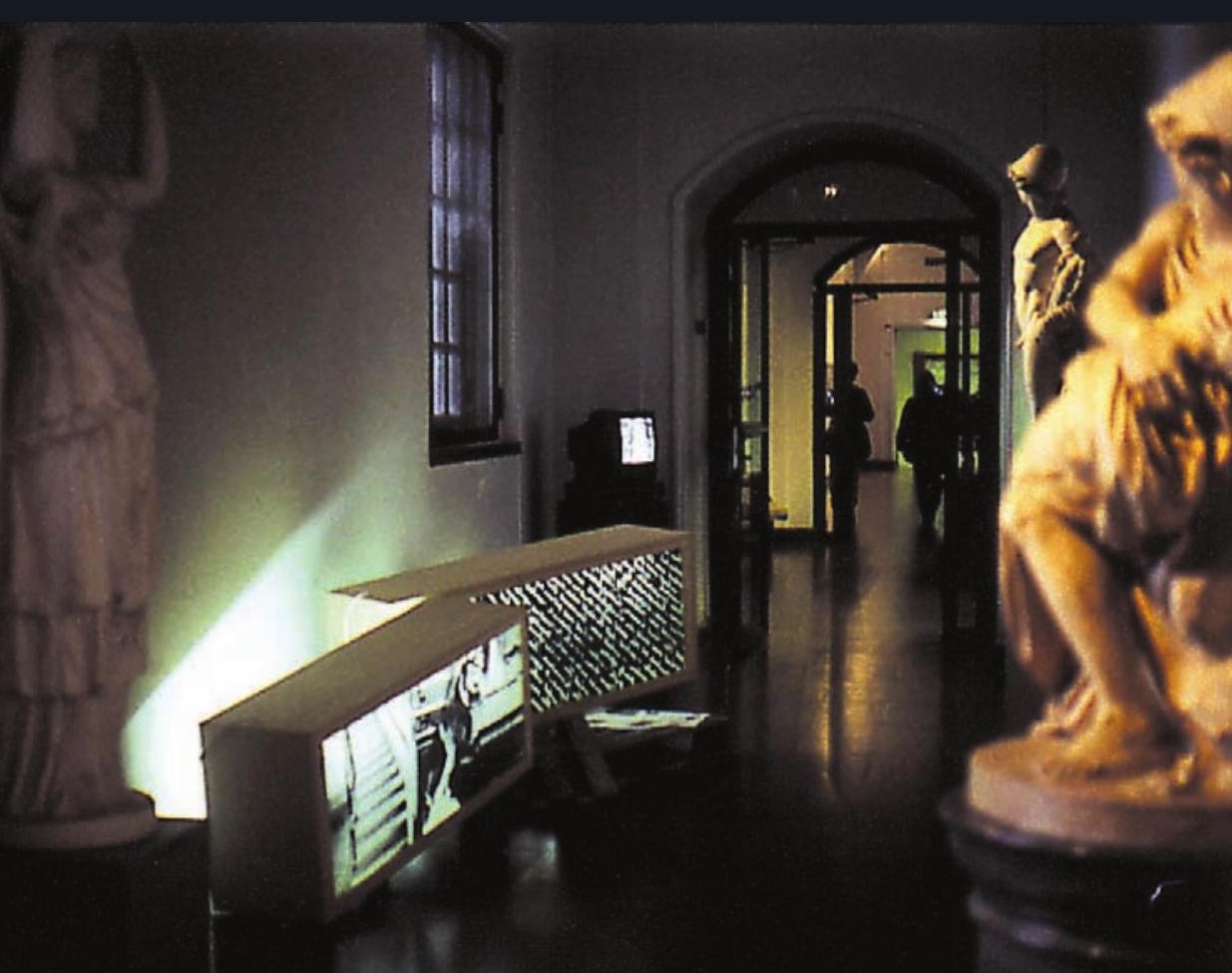


ten years earlier, a discovery that, together with the Hitler 4:00 a.m. bunker drawing, a long-ago conversation with a friend, and Sigrid Schade's invitation, came together with the production support of the OK to initiate the work.

Adaptations of Body Missing to different host venues, its translation into four languages and into cyberspace, and later still into digital photo-murals integrating details from earlier versions, and into image-text pieces (in Kunst als Beute, Eds. Sigrid Schade, Gottfried Fliedl,

Body Missing,

migrating.

FACING PAGE, TOP:

Offenes Kulturhaus, Linz, 1994: Partial view, façade, inaugural version of sixchannel video project.

FACING PAGE, BOTTOM:

Goeteborg Konstmuseum, 1998, (Station 6.) The OK windows have become coffin-sized light-boxes.

\section{THIS PAGE:}

Centre culturel canadien,

Paris, 2001. Video

sequences are transmuted into photo murals, one for each station, and the Body Missing website is now a key part of the installation.

Photo: Christian Lebrun, CCC, Paris.

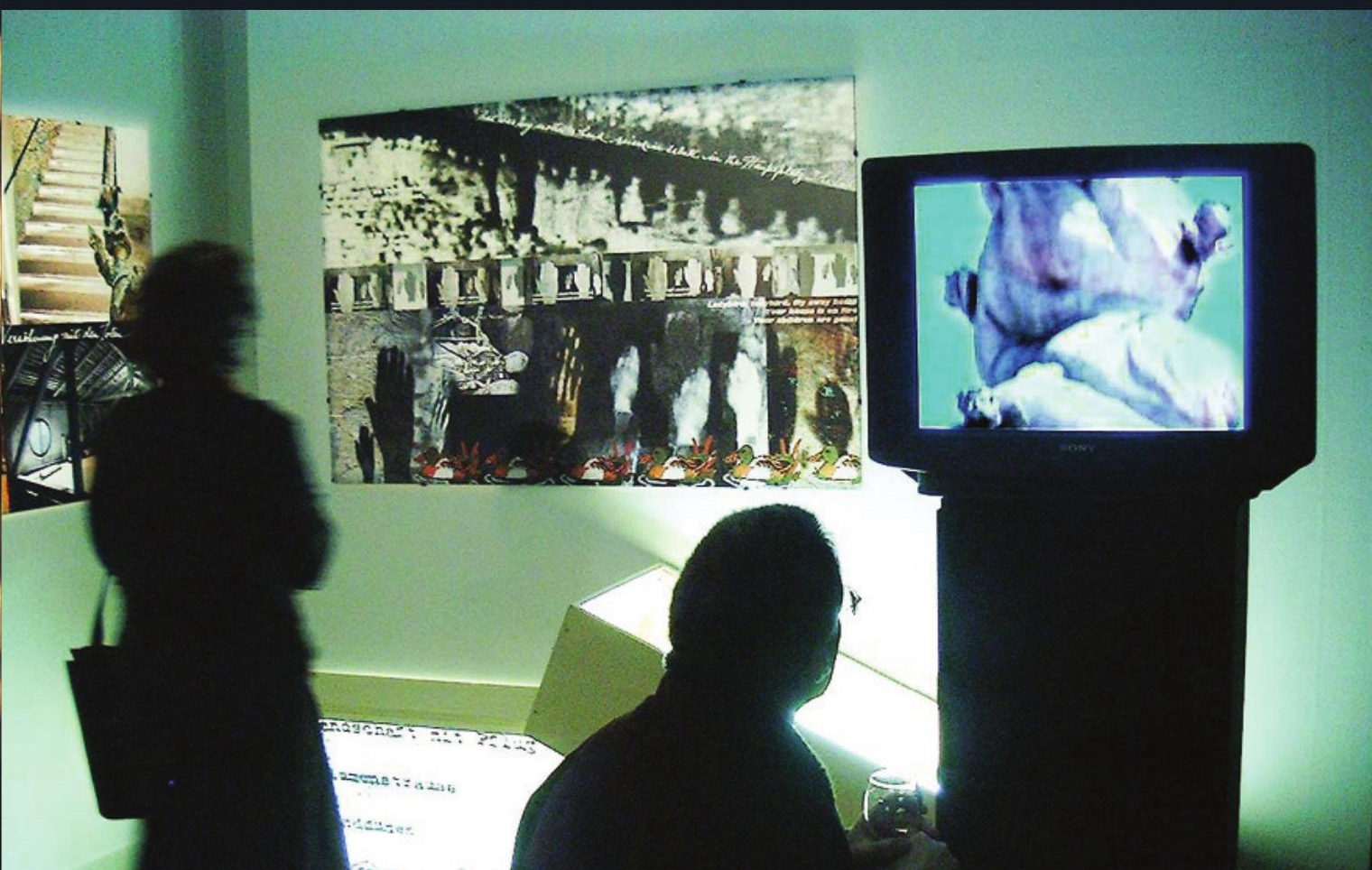


Turia \& Kant, Vienna, 2000) and Alphabet City (A Tangled Triangle: Strands of the Archive-Rhizome, "Lost in the Archives" issue, 2002) mark this work's capacity for migration.

The word "migration" used in this context is almost topographical, and does not connote the change in meaning that accompanies a change of medium, the transformative

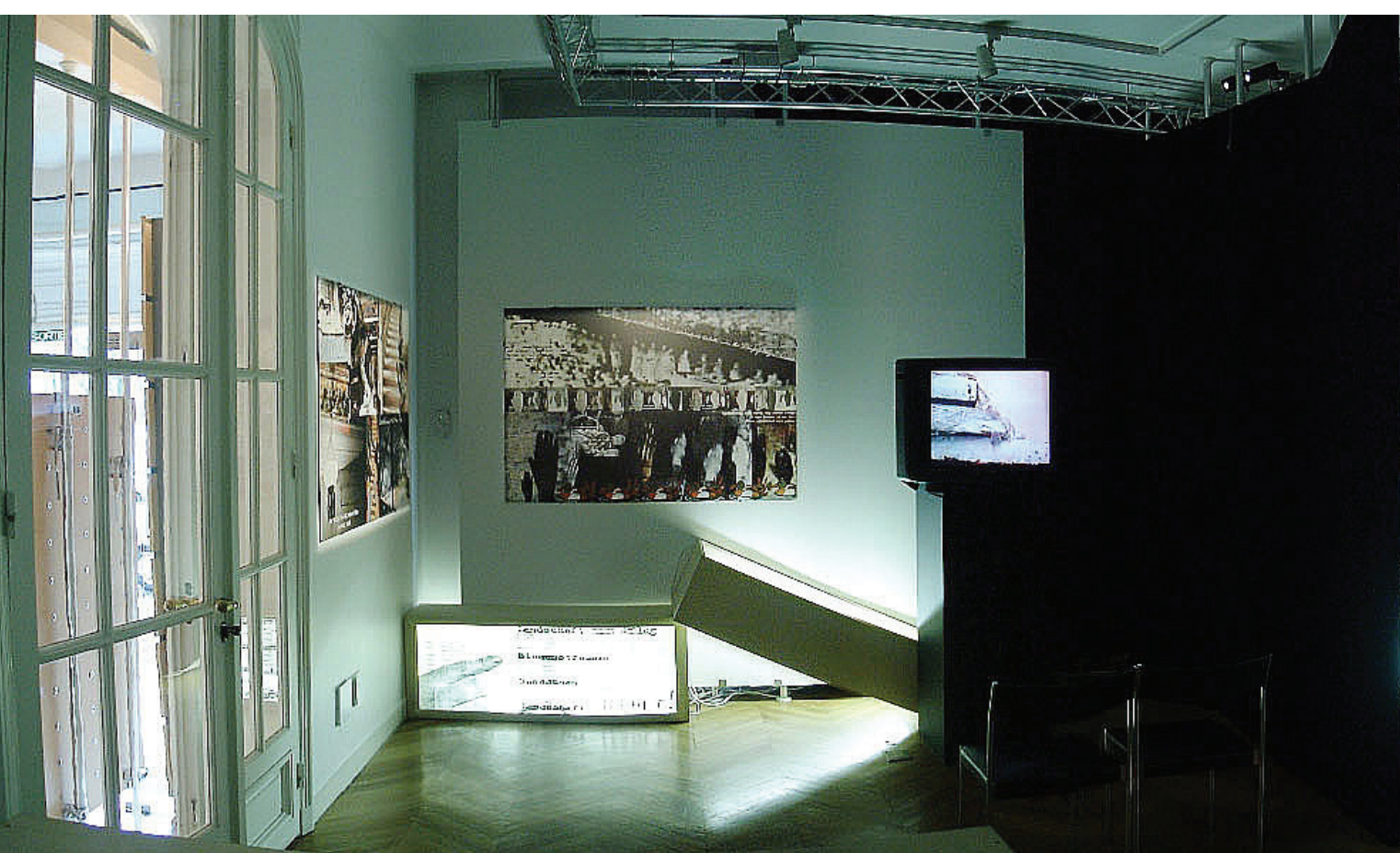



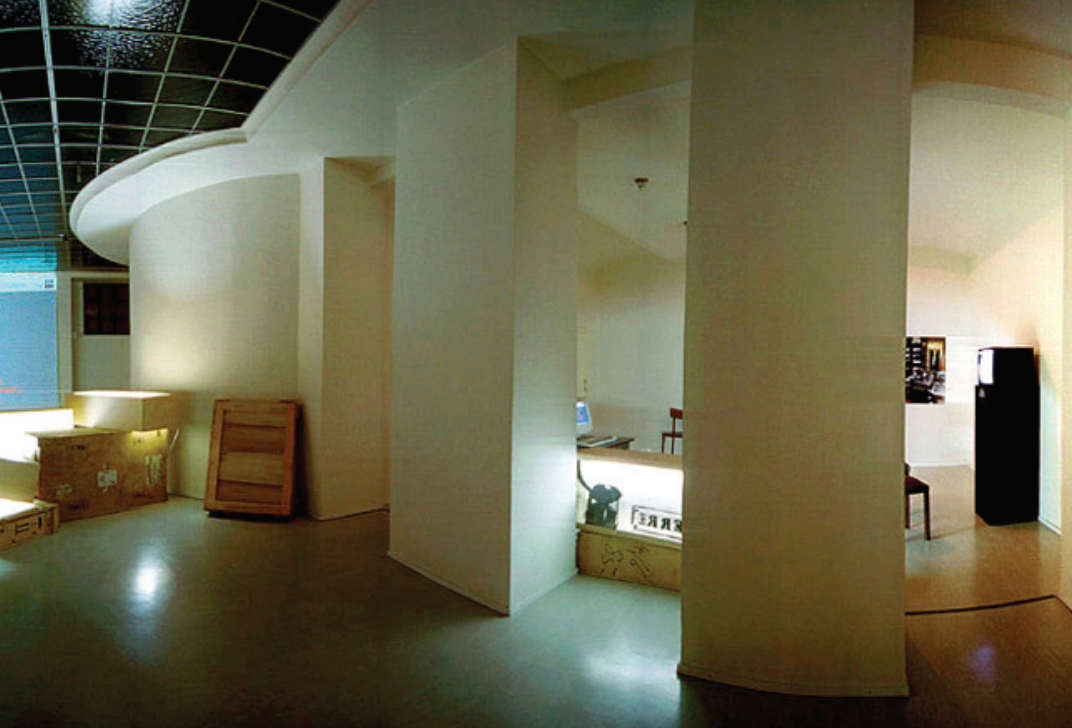

aspects of that process. Nevertheless, there's perhaps something to be said for the aura of healthcare that attaches in English to the term "remediation:" a rehabilitation or pharmaceutical nuance, suggesting that the shift from one medium to the next, despite inevitable losses of meaning, can also promise certain benefits as if with each change the art work is remedied, i.e., mended and improved.

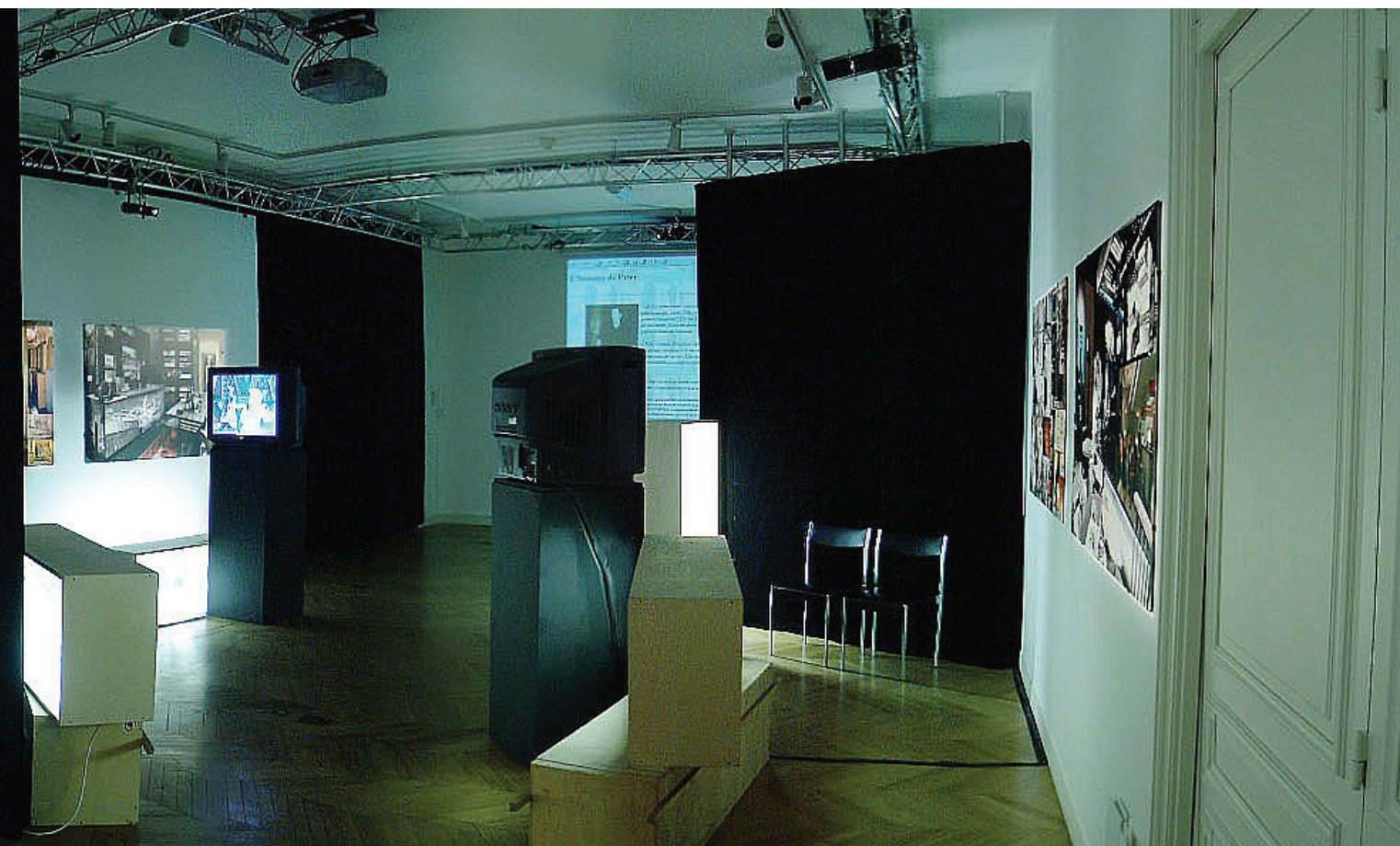


Lest this seem overly cheerful, now is the time, perhaps, to invoke the name of Marshall McLuhan, whose presence in Toronto contributed to the formative climate of ideas I found myself in as a young artist after leaving Montréal. McLuhan came of age as a public intellectual in Toronto and remains to this day a strong, if somewhat misperceived and grudgingly appreciated presence in that city. What is relevant to this discussion is of course his assertion that each new medium ingests its predecessor, a notion increasingly substantiated by the thralldom to new media that abounds, and the technical and moral quagmires this introduces.

While further migrations between different iterations of Body Missing are always possible, another kind of transition, as suggested above, informs the relation between that work in all its forms and my subsequent (and still ongoing) project:

The Institute ${ }^{\mathrm{TM}}$ : Or, What We Do for Love, a Web-based, multidisciplinary project on the travails of a dysfunctional cultural institution, includes site-specific physical components, digital prints, brass policy plaques, a website (the-national-institute. org) and "Dreadful Songs." I am currently planning three short videotapes based on the Social Workers' Reports from the website. In addition to its online development, the project in its physical entirety has traveled to three major venues in Canada, with two additional condensed versions installed in Toronto as well (April, 2004; September 2005). A second phase of the tour is in its planning stages (http://www.the-national-institute.org/tour).

Just as the seeds of my interest in art theft policies could be found in the previous two cycles of work (the Messiah 


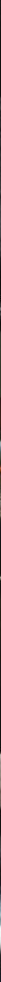

Two of the six Body Missing photo-murals, one for each video station, designed for the Detroit (Wayne State University Gallery), Toronto (Goethe-Institut) and Paris (Canadian Cultural Centre, 2001) versions. The video having migrated to DVD, Body Missing was now a webbased DVD installation with light-boxes and photo-murals.

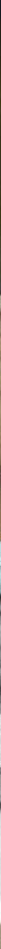




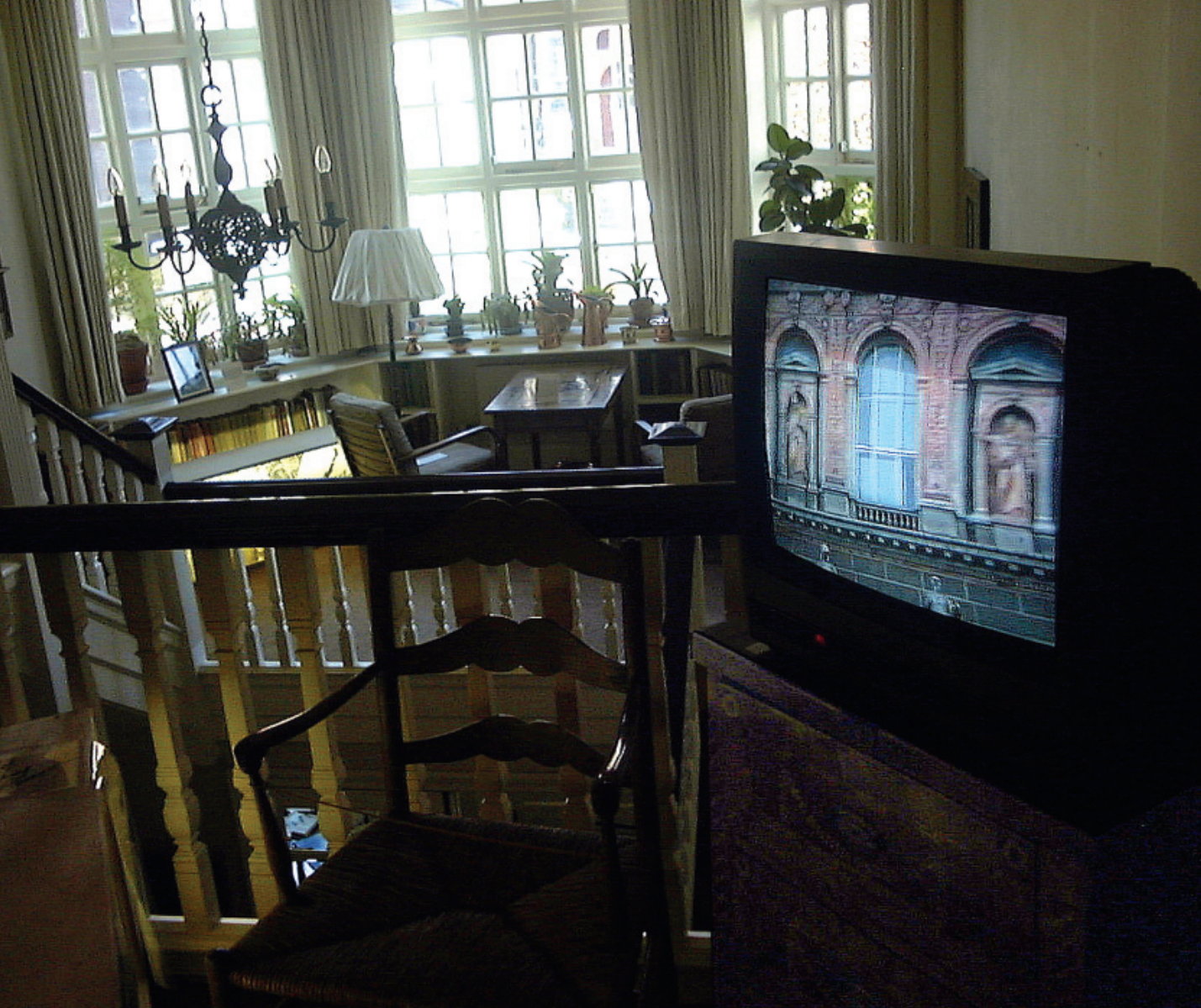

was quite different. Looking for props and furniture elements in Sudbury, for example, a legendary nickel-mining town in Northern Ontario, we found ourselves in basements carved directly out of dark pre-cambrian rock, looming jagged and glistening with mineral content. In these strange cave-like spaces under otherwise quite routine buildings, we discovered that the Sudbury of a certain era had a fondness for the colour turquoise. Filing cabinets, office chairs, desks, psychiatrist's couch all appeared in the same heightened aqua-blue. The Sudbury Institute ${ }^{\mathrm{TM}}$, therefore, had to have a blue room, and indeed it had, where visitors could relax on the psychiatrist's 


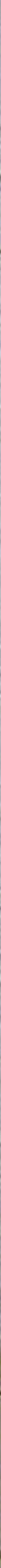






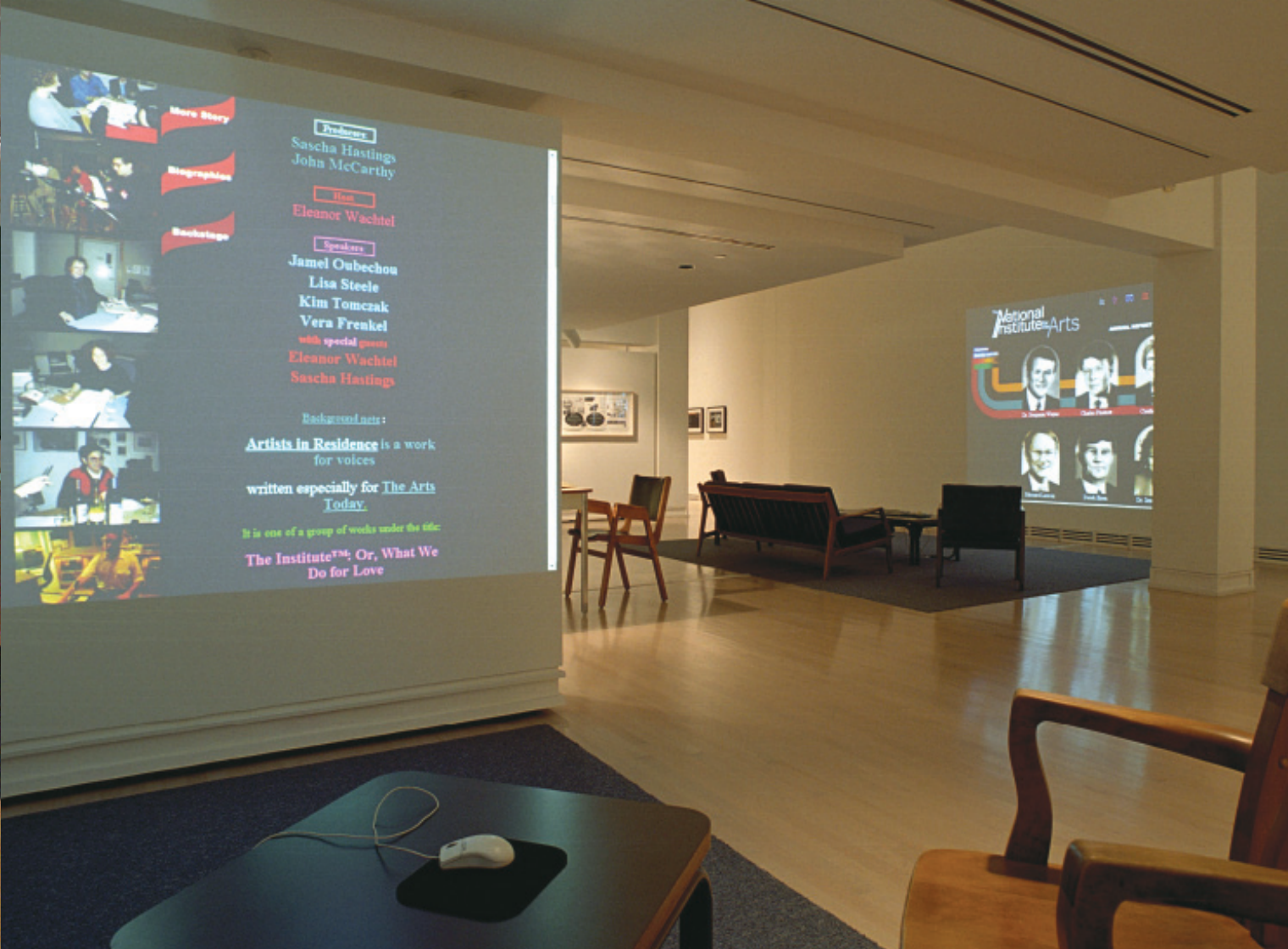

I think this large and changing project will accompany me for some time, as did Body Missing, Messiah Speaking, and earlier work cycles, each representing in a sense a core syntax rather than words, which I suppose may be axiomatic in works of this kind.

The latest remediation? After completing the recording of the full cycle of the seven "Dreadful Songs"-instrumentation and vocal harmonies have been recorded for the first threeand after completing the website's German version which is now in production, and the three short videotapes of the Social Worker's Reports, there will be a pause for a new image-text work into which elements from the whole will be distilled. This will require immersion in the contradictions, 
ambivalences and dialectics of The Institute ${ }^{\mathrm{TM}}$ and its various unfortunate models in the real world.

As I write this, I see that implicit in this project is a hopeful assumption that it is possible to govern and be governed well, and to create a society in which art in all its forms can be acknowledged as the engine that it is. In the meantime, the corollary task is to reflect the far less hopeful conditions that actually exist.

The calcifying impact of certain forms of cultural bureaucracy aren't the only forces destructive to art and to well-being, though often the least visible. Floods, studio moves, divorces, deaths and clumsy de-accessioning procedures are powerful editing processes. In an inevitable, organic and unpredictable process, some artworks survive, others don't.

The next migration of The Institute $\mathrm{TM}^{\mathrm{TM}}$ may be towards creating or recreating projects as imagined by its residents, artworks which have been lost or dispersed for lack of support or of space in which to display or safeguard them. If I place myself among the semi-fictive artists in The Institute ${ }^{\mathrm{TM}}$ and from that position realize their lost works, I would be acknowledging and giving form to the arbitrariness of what survives, as well as continuing a pattern which began with String Games: Improvisations for Inter-City Video, (Montréal-Toronto, 1974), and which also informed other works - including those discussed here - a pattern of involving colleagues and friends in working confirmation of the inevitability of change. 


\section{mational /nstitute Arts}

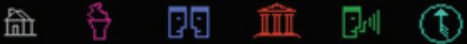

\section{Chairman}

Director and CEO

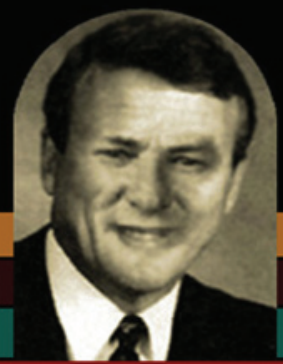

Dr. Benjamin Wayne

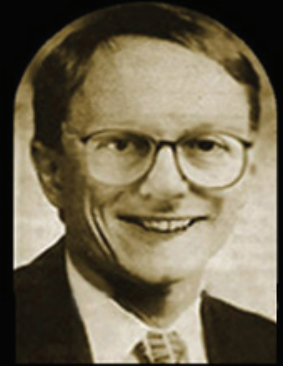

Edouard Lacroix

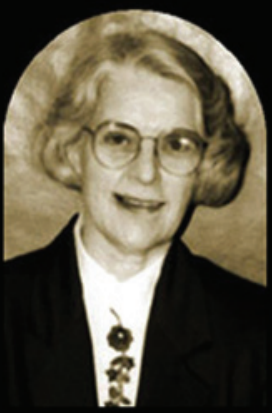

Mary-Jo Simpson

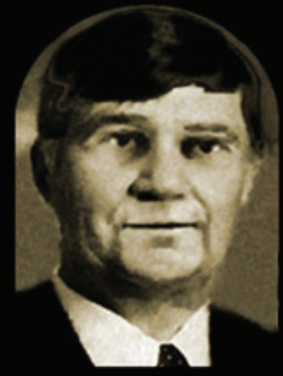

Derek Eisen

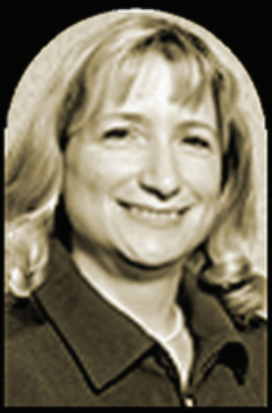

Jayne M. Farnsworth

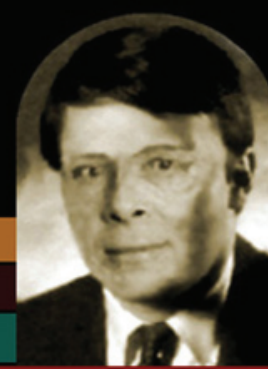

Charles Plaskett

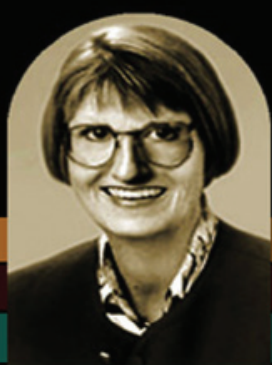

Cynthia Marinelli

ANNUAL REPORT

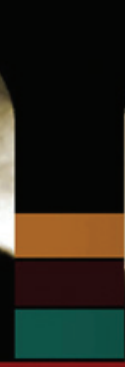

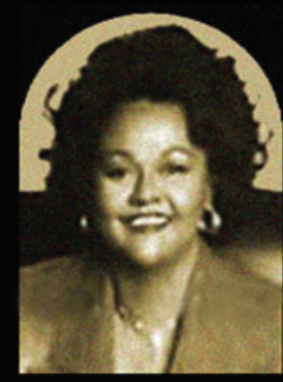

Dr. Irma O'Connor

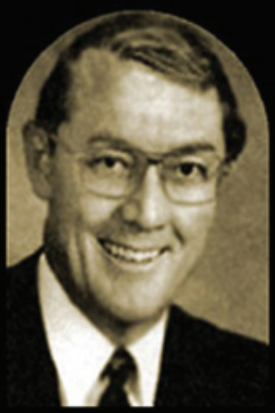

Walker Duchesne
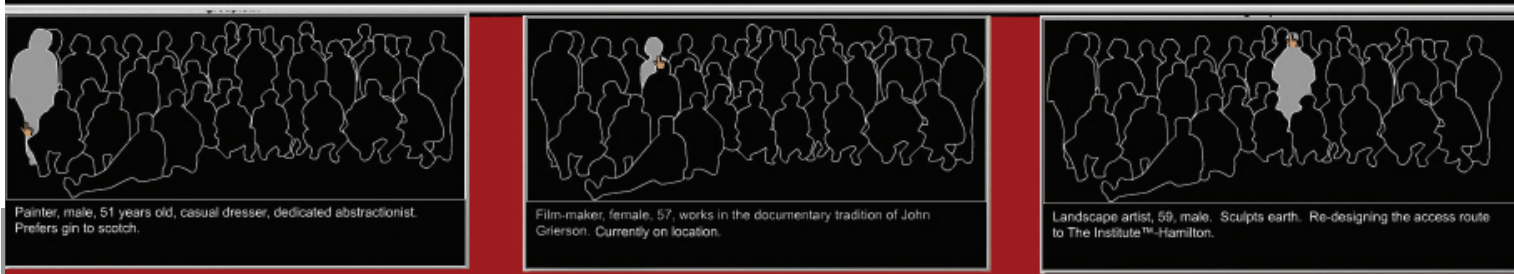

Detail of frame capture from The Institute $\mathrm{TM}$ : Or, What We Do for Love website.

Annual Report page showing current Members of the Board, each provided with a pop-up biography. 


\section{Légendes des images}

\section{PAGE 147}

\section{Top}

The Screening Room, multidisciplinary installation, 1983, for viewing the videotape, "Stories from the Front (\& the Back)" [Western Front, 1981], partial view. Gallery, Minneapolis College of Art \& Design, Mpls. Curator: Diane Shamash.

\section{Centre}

The Screening Room, partial view, MCAD Gallery, 1983. Photo: Rik Sferra

\section{Bottom}

The Last Screening Room: A Valentine, videotape, 1984. R.T. 44 minutes. Video still from sequence shot in the 1983 Minneapolis installation. On camera: Vera Frenkel, Rik Sferra.

\section{PAGE 148}

Top

This Is Your Messiah Speaking, video installation, two-channel version, Newcastle, U.K., 1990.

\section{Centre}

Messiah Speaking, computer animation, Piccadilly Circus Spectacolor Board, London, England. 199091, Artangel Trust Commission. Opening frame of animated sequence as seen from the roof of the London Pavilion.

\section{Bottom}

"There's No Rush," frame from Messiah Speaking, Piccadilly Circus Spectacolor Board, London. 1990-91. Photo: Harry Chambers, The Artangel Trust.

\section{PAGE 150}

“... from the Transit Bar," partial view, six-channel videodisk installation and functional piano bar, documenta IX, 1992, Kassel. Curator: Denys Zacharopolous. Photo: Dirk Bleicker.

\section{PAGE 151}

Recovering Memory, partial view, audio installation using reconfigured Transit Bar elements and Disklavier, 1993, Art Gallery of York University, Toronto. Curator: Loretta Yarlow. Photo: Isaac Applebaum.

\section{PAGE 152}

“... from the Transit Bar," partial view, 1994-95, Power Plant Gallery of Contemporary Art, Toronto. Photo: Isaac Applebaum.

\section{PAGE 153}

“... from the Transit Bar" partial view, National Gallery of Canada, Ottawa, 1996. Curator: Jean Gagnon. Photo: Charles Hupé, National Gallery.

\section{PAGE 154}

From the Body Missing web site (www.yorku.ca/ BodyMissing), 1995

Opening page

\section{PAGE 155}

The Transit Bar, now fictively in Linz

\section{PAGE 156}

Top

Site map

\section{Bottom}

Hitler's collection and the 1937 Great Art Exhibition

\section{PAGE 157}

The bartender's story

\section{PAGE 159}

Top

1938 map of Linz; subtitle of narrative

\section{Bottom}

The piano-players' page

\section{PAGE 160}

\section{Top}

Body Missing, six-station video-photo-text installation, 1994. Detail of front façade, Offenes Kulturhaus, Linz, Austria. Inaugural version for Andere Körper exhibition and symposium. Curator: Sigrid Schade. 


\section{Bottom}

Body Missing, detail of installation, Station 6: "The Process of Redemptive Naming Begins/ Début du processus nominatif rédempteur," Göeteborg Konstmuseum, Sweden. Last stop on Riksutställningar tour, 1997-98. Curators: Ulla Arnell, Tom Sandqvist.

\section{PAGE 161}

Body Missing, detail, Video stations 1 and 2: "Reconciliation with the Dead / Réconciliation avec la mort" and "Recalling the Benign World of Things / Rappel de la bienveillance du monde des choses". Light boxes, photo-murals, website. Canadian Cultural Centre, Paris. Curator: Cathérine Bédard. Photo: Christophe Lebrun.

\section{PAGE 162-163}

\section{Top}

Body Missing, partial view, DVD installation, Station 5: "Athena's Polished Shield / Le bouclier brillant d'Athéna," and website projection. Georg Kargl Gallery, Vienna, 2002. Photo Karg1 Gallery.

\section{Bottom}

Body Missing, partial view, Canadian Cultural Centre, Paris 2001. Photo: Christophe Lebrun

\section{PAGE 165}

\section{Top}

Body Missing, detail, photo-mural for Station 4: "The Apparatus of Marking Absence / L appareil à marquer l'absence," 4' x 6', 2000.

\section{Bottom}

Body Missing, detail, photo-mural for Station 6: "The Process of Redemptive Naming Begins / Début du processus nominatif rédempteur," 4' x 6', 2000.

\section{PAGE 166}

Body Missing, detail, Station 2, in Freud's study, Freud Museum, London, 2003. Full museum DVD installation; subject of "Body Missing: From Theft to Virtuality," Symposium, I.C.A., London, March 21-22, 2003.

\section{PAGE 167}

Body Missing, detail. Station 4, overlooking the mezzanine, Freud Museum, London, 2003.

\section{PAGE 168-169}

Body Missing, in storage at the Georg Kargl Gallery, Vienna.

Photo: Liddy Scheffknecht, Georg Kargl Gallery.

\section{PAGE 170}

The Institute ${ }^{\mathrm{TM}}$ : Or, What We Do for Love, webbased multidisciplinary installation. Partial view, showing Screen 2. Justina M. Barnicke Gallery, Hart House, University of Toronto, 2003.

\section{PAGE 171}

The Institute ${ }^{\mathrm{TM}}$ : Or, What We Do for Love, webbased multidisciplinary installation. Partial view, showing Screen 3 (near camera on left) and Screen 1 (far right). Project Manager: Mark Jones. Curator: Sandra Dyck. Photo, David Barbour, 2005.

\section{PAGE 173}

\section{Top}

The Institute ${ }^{\mathrm{TM}}$ : Or, What We Dofor Love, website frame capture (www.the-national-institute.org). Detail of Board of Directors page, 2003 and ongoing.

\section{PAGE 174-175}

The Institute ${ }^{\mathrm{TM}}$ : Or, What We Do for Love, detail: The Blue Room, for listening to the "Dreadful Songs.” Art Gallery of Sudbury, 2004. 